\title{
Usefulness of Early C-Reactive Protein Kinetics in Response and Prognostic Assessment in Infected Critically III Patients: An Observational Retrospective Study
}

\section{A Utilidade da Cinética Precoce da Proteína C-Reativa para Avaliar a Resposta e Prognóstico nos Doentes Críticos Infectados: Um Estudo Observacional Retrospetivo}

\author{
Marta Ayres PEREIRA $\rrbracket^{1}$, Ana Lídia ROUXINOL-DIAS ${ }^{2,3}$, Tatiana VIEIRA ${ }^{4}$, José Artur PAIVA ${ }^{4,5,6}$, \\ José Manuel PEREIRA ${ }^{4,5,6}$
}

Acta Med Port 2019 Dec;32(12):737-745 - https://doi.org/10.20344/amp.12143

\section{ABSTRACT}

Introduction: The ideal biomarker to assess response and prognostic assessment in the infected critically ill patient is still not available. The aims of our study were to analyze the association between early C-reactive protein kinetics and duration and appropriateness of antibiotic therapy and its usefulness in predicting mortality in infected critically ill patients.

Material and Methods: We have carried out an observational retrospective study in a cohort of 60 patients with community-acquired pneumonia, aspiration pneumonia and bacteremia at an intensive care unit. We have collected C-reactive protein consecutive serum levels for eight days as well as duration and appropriateness of initial antibiotic therapy. C-reactive protein kinetic groups were defined based on the levels at days 0, 4 and 7. With a follow-up of one year, we have evaluated mortality at different time-points.

Results: We have obtained three different $\mathrm{C}$-reactive protein kinetic groups from the sample: fast response, delayed but fast response and delayed and slow response. We did not find statistically significant associations between C-reactive protein kinetics and early (intensive care unit, hospital and 28-days) or late (six months and one year) mortality and antibiotic therapy duration $(p>0.05)$. Although there were no statistically significant differences between the appropriateness of antibiotic therapy and the defined groups $(p=0.265)$, no patient with inappropriate antibiotic therapy presented a fast response pattern.

Discussion: Several studies suggest the importance of this protein in infection.

Conclusion: Early C-reactive protein kinetics is not associated with response and prognostic assessment in infected critically ill patients. Nevertheless, a fast response pattern tends to exclude initial inappropriate antibiotic therapy.

Keywords: Biomarkers; C-Reactive Protein; Critical Care; Infection; Intensive Care Units; Kinetics; Portugal

\section{RESUMO}

Introdução: O biomarcador ideal capaz de avaliar a resposta e prognóstico no doente crítico infetado ainda não está disponível. Os objetivos do nosso estudo foram avaliar a relação da cinética precoce da proteína C-reativa com a duração e apropriação da terapêutica antibiótica e a sua utilidade na predição de mortalidade.

Material e Métodos: Realizámos um estudo retrospetivo observacional numa coorte de 60 doentes com pneumonia adquirida na comunidade, pneumonia de aspiração e bacteremia numa unidade de cuidados intensivos. Colhemos níveis séricos de proteína C-reativa durante oito dias e a duração e apropriação da terapêutica antibiótica inicial. Definimos grupos de cinética de proteína C-reativa com base nos níveis dos dias 0, 4 e 7. Durante um ano de seguimento, analisámos a mortalidade em diferentes momentos. Resultados: Da amostra obtivemos três grupos de cinética de proteína C-reativa: resposta rápida, resposta atrasada mas rápida e resposta atrasada e lenta. Não observamos associação estatisticamente significativa entre a cinética da proteína C-reativa com a mortalidade precoce (unidade de cuidados intensivos, hospital e aos 28 dias) ou tardia (seis meses e um ano) e duração da terapêutica antibiótica $(p>0,05)$. Embora não existam diferenças estatisticamente significativas entre a apropriação da terapêutica antibiótica e os grupos definidos $(p=0,265)$, nenhum doente com terapêutica antibiótica inapropriada apresentou um padrão de resposta rápida. Discussão: Vários estudos sugerem a importância desta proteína na infeção.

Conclusão: A cinética precoce da proteína C-reativa não está associada com a avaliação da resposta e prognóstico no doente crítico infectado. Porém, um padrão de resposta rápida tende a excluir terapêutica antibiótica inicial inapropriada.

Palavras-chave: Biomarcadores; Cinética; Cuidados Críticos; Infeção; Portugal; Proteína C-Reativa; Unidades de Cuidados Intensivos

\section{INTRODUCTION}

More than half of patients admitted to an intensive care unit (ICU) are infected. Infection is a major cause of morbidity and mortality in the critically ill patient, with the respiratory tract being one of the main focus of infection. ${ }^{1}$ Community-acquired pneumonia (CAP) is a major death cause in the western world ${ }^{2}$ with an estimated mortality rate of $25 \%-40 \%$ in patients admitted to the ICU. ${ }^{3,4}$ Bacteremia

\footnotetext{
1. Faculty of Medicine. University of Porto. Porto. Portugal.

2. Anesthesiology Department. Centro Hospitalar Universitário São João. Porto. Portugal.

3. Center for Research in Health Technologies and Information Systems. Faculty of Medicine. University of Porto. Porto. Portugal.

4. Emergency and Intensive Care Department. Centro Hospitalar Universitário São João. Porto. Portugal.

5. Infection and Sepsis Group. Porto. Portugal.

6. Medicine Department. Faculty of Medicine. University of Porto. Porto. Portugal.

$\square$ Autor correspondente: Marta Ayres Pereira. marta.ayres.pereira@gmail.com

Recebido: 05 de abril de 2019 - Aceite: 14 de junho de 2019 | Copyright @ Ordem dos Médicos 2019
} 
is the third cause of infection in the $\mathrm{ICU}^{1}$ with a rate that will probably increase over time. ${ }^{5}$ Aspiration pneumonia (AP) is also common in ICU, especially in elderly patients. ${ }^{6}$

Since it is not always possible to determine the infectious etiology, in particular at the beginning of the disease course, empirical antibiotic therapy is adopted based on the patient's clinical data. In the critically ill patient, broad spectrum antibiotics are frequently used as an attempt to cover all likely pathogens involved. However, this strategy is associated with higher costs, high risk of side effects and emergence of antimicrobial resistance. ${ }^{7}$ The usefulness of several inflammatory biomarkers to support diagnosis and evaluate therapeutic response and prognosis of infected patients has been largely studied. Nevertheless, the ideal biomarker, combining high sensitivity and high specificity, is not yet available. ${ }^{8,9}$

Discovering the ideal biomarker to assess response to antibiotic therapy and to predict outcome in the infected critically ill patient would improve patient management and the allocation of health care resources.

First discovered and named for its reaction with the pneumococcal C-polysaccharide by Tillet et al, ${ }^{10} \mathrm{C}$-reactive protein (CRP) is a homopentameric acute phase protein with pro and anti-inflammatory properties and is involved in acute immunological responses which make it a member of the pentraxin protein family. ${ }^{11}$ Mostly produced in the liver in response to the increase of inflammatory cytokines, in particular interleukin-6, CRP binds to polysaccharides in microorganisms, activating the classical complement pathway of innate immunity ${ }^{12}$ promoting activity against the infection as it has been demonstrated previously in mice infected with Streptococcus pneumoniae. ${ }^{13}$ After the stimulus, CRP levels rise within 4 to 6 hours, double every 8 hours and show a maximum peak concentration in 36 to 50 hours. When the stimulus is removed, its concentration drops, with a half-life of 19 hours. ${ }^{14}$ Widely studied as a biomarker, CRP concentration is higher in infected patients compared to patients without infection. CRP concentration above $8.7 \mathrm{mg} / \mathrm{dL}$ supports a diagnosis of infection in patients with a body temperature above $38.2^{\circ} \mathrm{C} .{ }^{15}$ In severe infections, CRP reaches levels more than 1000 times above the baseline level. However, it does not help locate the infection site. ${ }^{14,16}$

CRP also increases in non-infectious conditions such as autoimmune diseases, malignant tumors, surgeries, trauma, burns, vigorous exercise, acute myocardial infarction and also in some psychiatric diseases. However, there are some inflammatory diseases, such as lupus erythematosus, in which CRP remains normal or slightly elevated. ${ }^{14}$

Previously, four distinct patterns of CRP as a marker of different responses to antibiotic therapy were proposed: fast, slow, unresponsive and biphasic patterns. They are associated with distinct prognosis: patients with the patterns "fast" and "slow" response apparently have a better outcome compared to patients with "unresponsive" or "biphasic" patterns. ${ }^{14,17}$

The main aim of our study was to evaluate the association between early CRP kinetics and early and late mortality and antibiotic therapy duration in the critically ill patient. As secondary aim, we evaluate if the appropriateness of antibiotic therapy influences CRP kinetics.

\section{MATERIAL AND METHODS}

We conducted a single-center retrospective cohort study of patients with CAP, AP or bacteremia admitted in an ICU of Centro Hospitalar Universitário São João (CHUSJ), a tertiary hospital in the north of Portugal, from January 1 , 2016 to December 31, 2017, with one year of follow-up. The CHUSJ's ethics committee approved the study design.

All patients were 18 years of age or older. We excluded patients without CRP measurement on day 0 and 4 (both required for the classification of kinetic group) or without a minimum of seven days of follow-up. If the CRP measurement on day 7 was necessary for the classification of kinetic group and was not present, patients were also excluded. Patients with tuberculosis or Pneumocystis jirovecii pneumonia, immunosuppression or neutropenia were also excluded. Immunosuppression was considered present if the patient was under short term (daily dose of corticosteroids $\geq 1 \mathrm{mg} / \mathrm{kg}$ or $>40 \mathrm{mg}$ of oral prednisolone or equivalent for at least 1 week in the three months preceding the ICU admission) or long term (daily dose of $\geq 0.2 \mathrm{mg} / \mathrm{kg}$ prednisolone or equivalent during a minimum of 3 months in the 12 months preceding the ICU admission) corticosteroids use or if, in the prior year to hospital admission, any immunosuppressive therapy (including cytostatics) was used. Neutropenia was defined as an absolute neutrophils count $<1 \times 10^{9} /$ L. $^{18}$ We have included all eligible patients admitted during the aforementioned period.

Data was collected from the patient health record. For the analysis, we included demographic data (age, gender, hospital and ICU admission dates), co-morbidities, microbiological and simplified acute physiology score (SAPS) II calculated at ICU admission. ${ }^{19}$ According to previously published definitions, the recorded comorbidities were alcoholism, chronic heart failure, chronic kidney failure, chronic liver disease, chronic respiratory failure, diabetes mellitus, drug addiction, human immunodeficiency virus (HIV) or acquired immune deficiency syndrome (AIDS), neoplasia, neurological disease or traumatic brain injury. The definitions of comorbidities are set out in Appendix 1 (https:// www.actamedicaportuguesa.com/revista/index.php/amp/ article/view/12143/5806). ${ }^{18,20}$

The diagnosis of CAP, AP and bacteremia were analyzed as mutually exclusive primary diagnoses. CAP was diagnosed when, in addition to suggestive clinical features (e.g. cough, fever, sputum production, pleuritic chest pain), a demonstrable infiltrate was present in chest radiograph or computed tomography scan. ${ }^{21}$ If this clinical picture was the result of aspiration of either oropharyngeal or gastric contents into the lower airways, it was classified as aspiration pneumonia. Pneumonia was classified as microbiologically documented if a non-skin contaminant microorganism was isolated in blood culture or pleural fluid, urinary antigens were positive for Legionella pneumophila or Streptococcus 
pneumoniae, polymerase chain reaction for respiratory virus was positive or if there was a significant bacterial growth of a pathogen in a good quality lower respiratory tract sample.

Bacteremia was classified as primary if no source was identified or as secondary if an infection source was identified and the same pathogen was simultaneously isolated in blood cultures and the infection site. In addition, bacteremia was classified according to the place of acquisition as community-acquired, hospital-acquired and ICU-acquired. If the infection was diagnosed within the first 48 hours of hospital admission and it was not associated with invasive therapeutic procedures performed in healthcare institutions, we classified it as community-acquired bacteremia. If the infection was diagnosed more than 48 hours after hospital admission or it was clearly associated with invasive therapeutic procedures performed in healthcare institutions, we classified it as hospital-acquired bacteremia. If it was diagnosed more than 48 hours after ICU admission, we classified it as ICUacquired bacteremia. ${ }^{18}$ We decided not to include patients with hospital-acquired pneumonia or ventilator associated pneumonia due to the inherent subjectivity in defining the moment of infection compared to other diagnoses.

The start date of antibiotic therapy corresponded to the first day of empirical or directed antibiotic therapy prescribed in one of the three established diagnoses. Empirical antibiotic therapy was defined as antibiotic therapy with no microbiological data. Whenever microbiological documentation and respective antibiogram existed, initial antibiotic therapy was classified as appropriate or inappropriate. Antibiotic therapy was considered appropriate if the bacteria was susceptible in vitro, at least, to one antibiotic prescribed within the first 12 hours after presentation. If the bacteria were resistant in vitro to all antibiotics prescribed within the first 12 hours of presentation, antibiotic therapy was classified as inappropriate. In the absence of microbiological documentation, the appropriateness of initial antibiotic therapy was not evaluated. ${ }^{18}$ Total and appropriate antibiotic duration were collected.

Hospital and ICU length of stay were also recorded as well as the early (ICU, hospital and 28 days) and late (six months and one year) mortality rates.

For the purpose of time-dependent analysis, the first day of antibiotic therapy corresponded to day 0 . The following days were successively defined until day 7 . The day 0 corresponded to the first day of the eight CRP values collected. We have collected the highest level of lactate concentration at days 0, 4 and 7 and which patients have received vasopressor support between D0 and D7.

CRP pattern criteria were established based on the ratio between day 4 and day 0 , named initial CRP, and on the ratio of CRP between day 7 and day 0 , named late CRP. When an initial CRP ratio was $<0.4$, it was considered a fast response. When an initial CRP ratio was $\geq 0.8$, it was considered a delayed and slow response. When the initial CRP ratio was $\geq 0.4$ and $<0.8$, patients were classified according to late CRP ratio: biphasic response if late CRP ratio $\geq 0.8$ and delayed but fast response if $<0.8 .{ }^{17,22}$ These criteria are set out in Appendix 2 (https://www.actamedicaportuguesa. com/revista/index.php/amp/article/view/12143/5807).

We used IBM SPSS Statistics 25 and RStudio to perform descriptive statistical analysis, using median and interquartile range ( 25 - p75, IQR) for continuous variables and absolute and relative frequencies for categorical. Continuous variables were compared by the Kruskal-Wallis test after testing for normality of distribution and categorical variables by the Fisher's exact test. Results were considered statistically significant if $p<0.05$.

\section{RESULTS}

Our sample included 60 patients with a median age of 63.5 (IQR, 46.0 - 72.3) years (Table 1). Most participants were male ( $n=47 ; 78.3 \%)$, and $42(70 \%)$ had comorbidities. The most frequent comorbidities were diabetes mellitus $(28.3 \%)$, neoplasia (18.3\%), neurological disease/ traumatic brain injury (18.3\%) and alcoholism (16.7\%). The median SAPS II score at ICU admission was 49.0 (IQR, 32.8 - 65.5) points.

Regarding the infection type, 21 (35\%) patients had CAP, 19 (31.7\%) had AP and $20(33.3 \%)$ had bacteremia. CAP and AP were microbiologically documented in $57.1 \%$ and $78.9 \%$ of the cases, respectively. Bacteremia was hospital-acquired in $45 \%$ of the episodes, ICU-acquired in $30 \%$ and community-acquired in $25 \%$. Most of the cases of bacteremia $(80 \%)$ were secondary, mainly to intra-abdominal $(37.5 \%)$ and urological $(31.3 \%)$ infections.

The highest lactate concentration had a median value of 2.2 (IQR, $1.3-3.1) \mathrm{mmol} / \mathrm{L}$ at day 0 ( $\mathrm{n}=52$ patients), $1.4(\mathrm{IQR}, 1.1-1.9) \mathrm{mmol} / \mathrm{L}$ at day $4(\mathrm{n}=46$ patients $)$ and 1.3 (IQR, $0.9-1.6) \mathrm{mmol} / \mathrm{L}$ at day 7 ( $\mathrm{n}=34$ patients). In our sample, $39(65 \%)$ patients received vasopressors during the study period.

Antibiotic therapy was empirically started in 53 patients (88.3\%) while $7(11.7 \%)$ received initial directed therapy according to the antibiogram result. In our cohort, initial antibiotic therapy was appropriately prescribed in $83.0 \%$ ( $n=39$ patients) of patients and empirical antibiotic therapy was appropriately prescribed in $80.0 \%$ ( $n=32$ patients) of cases according to microbiological data.

The median overall antibiotic therapy duration was 9.0 (IQR, 7.0 - 14.0) days and while median appropriate antibiotic therapy duration was 10.0 (IQR, 8.0 - 14.0) days. Median ICU and hospital length of stay were 11.5 (IQR, $6.3-21.8)$ and 26.5 (IQR, 14.3 - 43.0) days, respectively.

ICU mortality was $8.3 \%$ ( $n=5$ patients) and $12(20 \%)$ patients died during hospitalization. No patients died within the first eight days after ICU admission. A total of eight (13.3\%) patients died 28 days after admission. At six months, the mortality rate was $31.7 \%(n=19$ patients $)$ and increased to $51.7 \%(n=31$ patients) at 12 months.

The CRP serum levels were recorded in all patients at days 0,4 and 5 . In days 1, 2, 3 and 7 we obtained CRP values in 58 patients. CRP serum levels were missing in four patients at day 6 . 
CRP time-dependent evolution patterns in response to initial antibiotic therapy are shown in Fig. 1 with median tendency line by CRP kinetics group of the whole cohort. Based on the previously defined criteria, we have obtained three CRP kinetic groups in our sample: fast response (FR),

Table 1 - Main demographic and clinical characteristics of the study sample

\begin{tabular}{|c|c|}
\hline & Total $(n=60)$ \\
\hline Male, n (\%) & $47(78.3)$ \\
\hline Age (years) ${ }^{1}$ & $63.5(46.0-72.3)$ \\
\hline $\begin{array}{l}\text { Comorbidities, } \mathrm{n}(\%) \\
\text { Alcoholism } \\
\text { Chronic heart failure } \\
\text { Chronic kidney disease } \\
\text { Chronic liver disease } \\
\text { Chronic respiratory failure } \\
\text { Diabetes mellitus } \\
\text { Drug addiction } \\
\text { HIVIAIDS } \\
\text { Neoplasia } \\
\text { Neurological disease/TBI }\end{array}$ & $\begin{array}{c}42(70) \\
10(16.7) \\
1(1.7) \\
9(15.0) \\
2(3.3) \\
5(8.3) \\
17(28.3) \\
2(3.3) \\
1(1.7) \\
11(18.3) \\
11(18.3)\end{array}$ \\
\hline SAPS II at ICU admission (points) ${ }^{1}$ & $49.0(32.8-65.5)$ \\
\hline $\begin{array}{l}\text { Community-acquired pneumonia, } \mathrm{n}(\%) \\
\text { Microbiological documentation, } \mathrm{n}(\%)\end{array}$ & $\begin{array}{c}21(35) \\
12(57.1)\end{array}$ \\
\hline $\begin{array}{l}\text { Aspiration pneumonia, } \mathrm{n}(\%) \\
\text { Microbiological documentation, } \mathrm{n}(\%)\end{array}$ & $\begin{array}{l}19(31.7) \\
15(78.9)\end{array}$ \\
\hline $\begin{array}{l}\text { Bacteremia } \\
\text { Community-acquired } \\
\text { ICU-acquired } \\
\text { Hospital-acquired } \\
\text { Primary } \\
\text { Secondary } \\
\text { Endovascular } \\
\text { Intra-abdominal } \\
\text { Pulmonary } \\
\text { Urological }\end{array}$ & $\begin{array}{l}20(33.3) \\
5(25.0) \\
6(30.0) \\
9(45.0) \\
4(20.0) \\
16(80.0) \\
3(18.8) \\
6(37.5) \\
2(12.5) \\
5(31.3)\end{array}$ \\
\hline $\begin{array}{l}\text { Median highest lactate concentration of } \\
\text { the day, }(\mathrm{mmol} / \mathrm{L})^{1} \\
\text { Day } 0^{\mathrm{a}} \\
\text { Day } 4^{\mathrm{b}} \\
\text { Day } 7^{\mathrm{c}}\end{array}$ & $\begin{array}{l}2.2(1.3-3.1) \\
1.4(1.1-1.9) \\
1.3(0.9-1.6)\end{array}$ \\
\hline Vasopressor support, $\mathrm{n}(\%)$ & $39(65)$ \\
\hline Appropriate antibiotic therapy, $n(\%)$ & $39(83.0)$ \\
\hline Overall antibiotic therapy duration (days) ${ }^{1}$ & $9.0(7.0-14.0)$ \\
\hline $\begin{array}{l}\text { Appropriate antibiotic therapy duration }{ }^{d} \\
\text { (days) }^{1}\end{array}$ & $10.0(8.0-14.0)$ \\
\hline ICU length of stay (days) ${ }^{1}$ & $11.5(6.3-21.8)$ \\
\hline Hospital length of stay (days) ${ }^{1}$ & $26.5(14.3-43.0)$ \\
\hline ICU mortality, n (\%) & $5(8.3)$ \\
\hline Hospital mortality, n (\%) & $12(20)$ \\
\hline 28-days mortality, $n(\%)$ & $8(13.3)$ \\
\hline 6 months mortality, $\mathrm{n}(\%)$ & $19(31.7)$ \\
\hline 1 year mortality, $\mathrm{n}(\%)$ & $31(51.7)$ \\
\hline
\end{tabular}

$\mathrm{N}$ : number of participants; 1 : data presented as median $\left(25^{\text {th }}-75^{\text {th }}\right.$ percentile); CAP: community acquired pneumonia; AP: aspiration pneumonia; TBI: traumatic brain injury. Relative frequencies of CAP, AP and Bacteremia are related to those diseases. Microbiologic documentation is related to CAP and AP. Missing data for: $a-8$ patients, $b-14$ patients, $c-26$ patients $\mathrm{d}-21$ patients. delayed but fast response (DFR) and delayed and slow response (DSR). We have not found a biphasic response in our sample.

Twelve patients $(20 \%)$ presented a FR with a median CRP concentration of 233.1 (IQR, 139.7 - 317.3) $\mathrm{mg} / \mathrm{L}$ on day 0 , of 65.9 (IQR, 38.9 - 96.2) $\mathrm{mg} / \mathrm{L}$ on day 4 and of 42.0 (IQR, 14.0 - 93.0) $\mathrm{mg} / \mathrm{L}$ on day 7. The 17 (28.3\%) patients in the DFR group had a median CRP concentration of 224.9 (IQR, $139.3-290.8) \mathrm{mg} / \mathrm{L}$ on day 0, 105.4 (IQR, 76.2 - 149.0) mg/L on day 4 and 61.0 (IQR, 39.0 - 86.0) $\mathrm{mg} / \mathrm{L}$ on day 7 . In the DSR group, which included 31 (51.7\%) patients, the median CRP concentration on day 0 was 73.6 (IQR, 25.8 - 181.0) mg/L, 146.6 (IQR, 104.4 - 208.6) mg/L on day 4 and 73.0 (IQR, 40.0 - 199.0) mg/L on day 7 .

When analyzing median CRP concentration evolution in patients with CAP: 1 (4.8\%) patient was in the FR group with a CRP concentration value of $71.8 \mathrm{mg} / \mathrm{L}$ on day $0,23.8 \mathrm{mg} / \mathrm{L}$ on day 4 and $8.0 \mathrm{mg} / \mathrm{L}$ on day $7 ; 9$ (42.9\%) were in the DFR group with a CRP concentration of 145.2 (IQR, 98.9 - 290.8) $\mathrm{mg} / \mathrm{L}$ on day 0, 102.9 (IQR, 49.4 - 192.1) $\mathrm{mg} / \mathrm{L}$ on day 4 and 74.0 (IQR, 39.0 - 162.0) mg/L on day 7; 11 (52.4\%) were in the DSR group with a CRP concentration of 64.3 (IQR, 25.8 - 112.8) $\mathrm{mg} / \mathrm{L}$ on day $0,126.8$ (IQR, $77.4-146.4)$ on day 4 and 50.0 (IQR, 40.0 - 156.0) mg/L on day 7 .

When analyzing median CRP concentration evolution in patients with AP: in the FR group with a CRP concentration of 149.8 (IQR,118.9 - 204.9) $\mathrm{mg} / \mathrm{L}$ on day 0 for $3(15.8 \%)$ patients, 39.0 (IQR, $38.7-42.2$ ) on day 4 for $3(15.8 \%)$ patients and 12.0 (IQR, 10.0 - 14.0) mg/L on day 7 for $2(10.5 \%)$ patients; $4(21.1 \%)$ were in the DFR group with a CRP concentration of 228.55 (IQR,166.0 - 268.1) mg/L on day $0,112.7$ (IQR, 81.2 - 129.4) $\mathrm{mg} / \mathrm{L}$ on day 4 and 56.0 (IQR, 42.0 - 64.0) $\mathrm{mg} / \mathrm{L}$ on day $7 ; 12(63.2 \%)$ were in the DSR group with a CRP concentration of 52.3 (IQR, 8.65 - 151.15) $\mathrm{mg} / \mathrm{L}$ on day $0,164.2(\mathrm{IQR}, 100.8-255.8) \mathrm{mg} / \mathrm{L}$ on day 4 and 78.0 (IQR, $40.0-217.0) \mathrm{mg} / \mathrm{L}$ on day 7 .

When analyzing median CRP concentration evolution in patients with bacteremia: $8(40 \%)$ patients were in the FR group with a CRP concentration of 288.7 (IQR, 205.9 - 364.8) $\mathrm{mg} / \mathrm{L}$ on day $0,90.55$ (IQR, 65.9 - 105.6) $\mathrm{mg} / \mathrm{L}$ on day 4 and 88.0 (IQR, 34.0 - 106.0) mg/L on day 7 ; $4(20 \%)$ were in the DFR group with a CRP concentration of 230.8 (IQR, $215.4-291.0) \mathrm{mg} / \mathrm{L}$ on day 0, 109.4 (IQR, 102.5 - 131.6) on day 4 and 73.0 (IQR, 49.0 - 104.0) mg/L on day 7 ; in the DSR group with a CRP concentration of 168.8 (IQR, 96.9 - 212.6) $\mathrm{mg} / \mathrm{L}$ on day 0 for $8(20 \%)$ patients, 165.1 (IQR, 160.9 - 195.5) on day 4 for 8 (20\%) patients and 162.0 (IQR, 37.0 - 203.0) mg/L on day 7 for seven $(35 \%)$ patients.

CRP time-dependent evolution patterns according to initial appropriate antibiotic therapy are shown in Fig. 2 with median tendency line by kinetic CRP group.

Mortality rate was evaluated at different time frames during the one-year follow-up period (Table 2). In the ICU, only one $(8.3 \%)$ patient died in the FR group, no patient in the DFR group of died, and in the DSR group, four (12.9\%) patients died, without statistically significant differences 


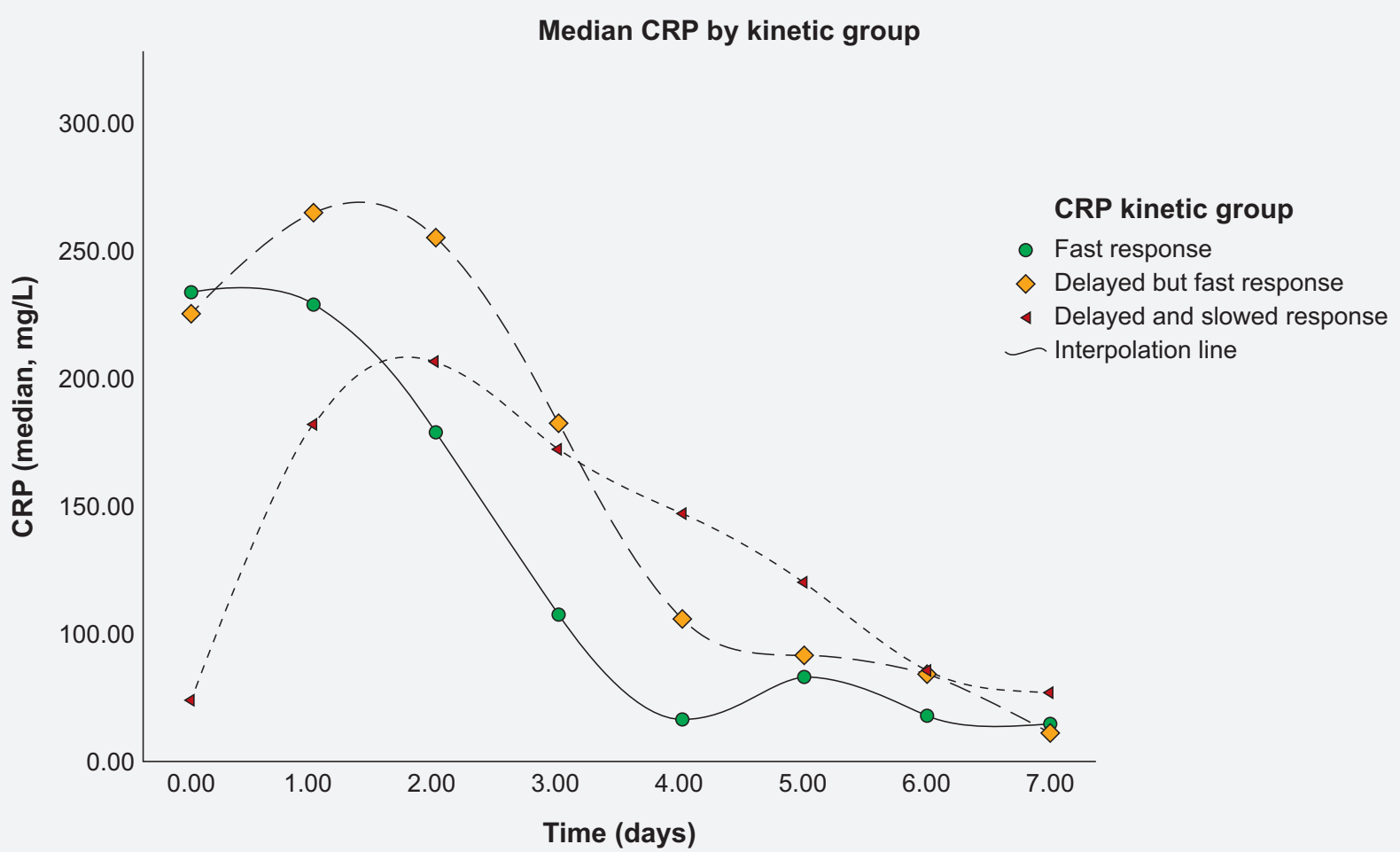

Figure 1 - C-reactive protein time-dependent patterns evolution in response to initial antibiotic therapy with median tendency

between the groups $(p=0.388)$. At the hospital, in the FR group one (8.3\%) patient died, in the DFR group two (11.8\%) patients died and in the DSR group nine $(29.0 \%)$ patients died, without statistically significant differences between the groups $(p=0.262)$. In the FR group, one (8.3\%) patient died more than 28 days after hospital admission, in the DFR group two (11.8\%) patients died and in the DSR group five (16.1\%) patients died, without statistically significant differences between the groups $(p=0.890)$. in the FR group, three $(25.0 \%)$ patients died more than six months after hospital admission, in the DFR group six (35.3\%) patients died and in the DSR group 10 (32.3\%) patients died, without

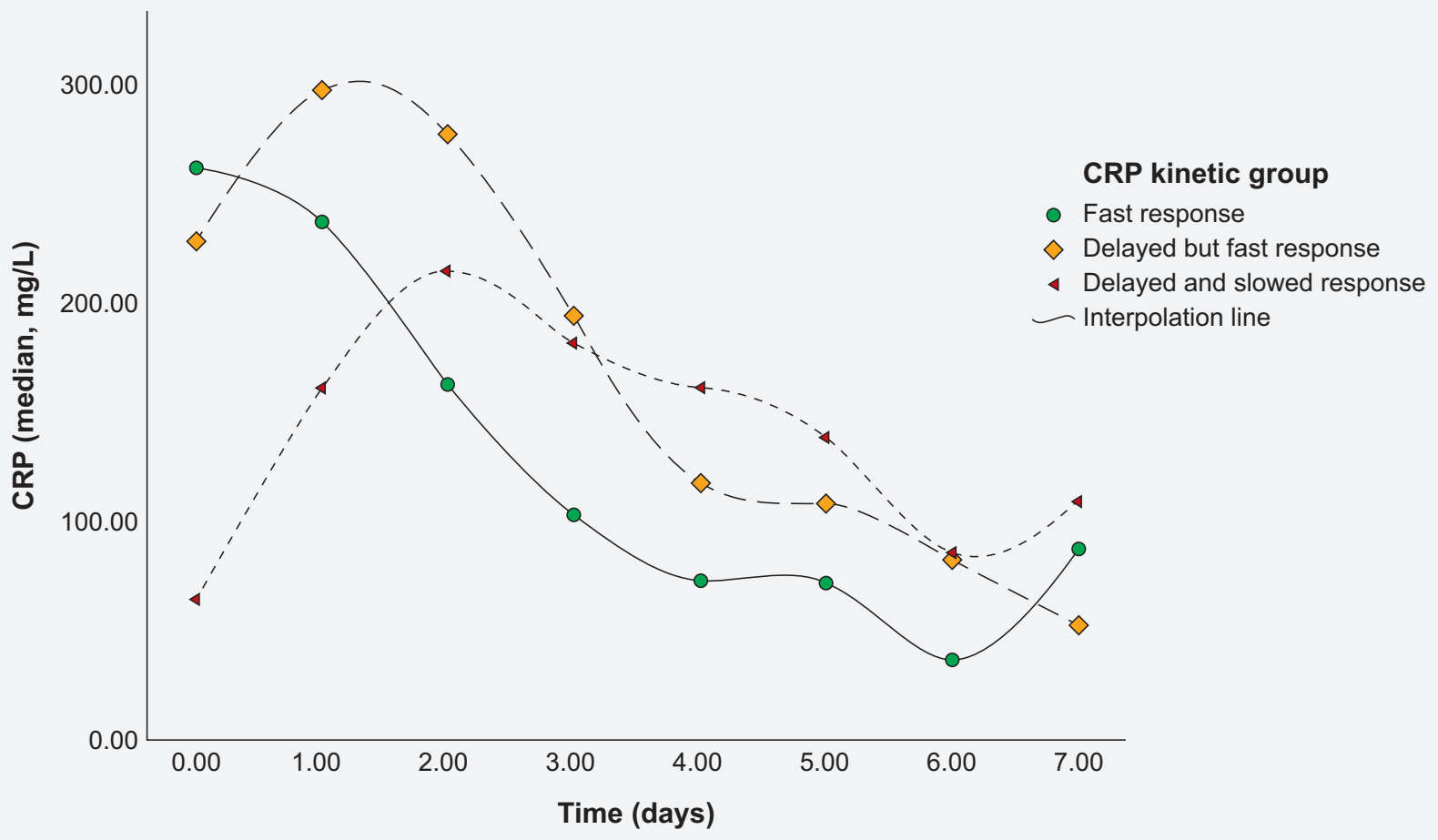

Figure 2 - C-reactive protein time-dependent patterns evolution in response to initial appropriate antibiotic therapy with median tendency 
Table 2 - Mortality in the different C-reactive protein kinetic groups

\begin{tabular}{lcccccc}
\hline & & \multicolumn{4}{c}{ Risk of death within... } \\
\cline { 3 - 7 } $\begin{array}{c}\text { CRP Kinetic } \\
\text { group }\end{array}$ & $\mathbf{N}$ & $\begin{array}{c}\text { ICU } \\
\mathrm{n}(\%)\end{array}$ & $\begin{array}{c}\text { Hospital } \\
\mathrm{n}(\%)\end{array}$ & $\begin{array}{c}\mathbf{2 8} \text { days } \\
\mathrm{n}(\%)\end{array}$ & $\begin{array}{c}\mathbf{6} \text { months } \\
\mathrm{n}(\%)\end{array}$ & $\begin{array}{c}\mathbf{1} \text { year } \\
\mathrm{n}(\%)\end{array}$ \\
\hline FR & 12 & $1(8.3)$ & $1(8.3)$ & $1(8.3)$ & $3(25.0)$ & $3(25.0)$ \\
DFR & 17 & $0(0.0)$ & $2(11.8)$ & $2(11.8)$ & $6(35.3)$ & $7(41.2)$ \\
DSR & 31 & $4(12.9)$ & $9(29.0)$ & $5(16.1)$ & $10(32.3)$ & $11(35.5)$ \\
$p$-value & & $0.388^{*}$ & $0.262^{*}$ & $0.890^{*}$ & $0.873^{*}$ & $0.673^{*}$ \\
\hline
\end{tabular}

CRP: C-reactive protein; CRP: kinetic groups: FR: fast response; DFR: delayed but fast response; DSR: delayed and slow response; ICU: intensive care unit; $\mathrm{n}$ : number of participants. Variables were compared by the Fisher's exact test. *none of the $p$-value was statistically significant, $p>0.05$.

statistically significant differences between the groups $(p=$ $0.873)$. In the FR group, three (25.0\%) patients died more than one year after hospital admission, in the DFR group seven $(41.2 \%)$ patients died and in the DSR group 11 (35.5\%) patients died, without statistically significant differences between the groups $(p=0.673)$.

In Fig. 3 we present the total duration of antibiotic therapy by kinetics group. The median value of duration of antibiotic therapy was 9.5 (IQR, $8.0-16.0$ ) for the FR group, 8.0 (IQR, 7.0 - 14.0) for the DFR group and 11.0 (IQR, 7.0 - 14.0) for the DSR group. We did not find statistically significant differences between the kinetics group and duration of antibiotic therapy $(p=0.472)$.

According to the appropriateness of antibiotic therapy (Table 3), if initial antibiotic therapy was appropriate, $28.2 \%$ ( $n=11$ patients) had a FR, 20.5\% ( $n=8$ patients) had DFR and $51.3 \%$ ( $n=20$ patients) had DSR. On the other hand, if initial antibiotic therapy was inappropriate, no patients had a FR, 37.5\% ( $n=3$ patients) had DFR and $62.5 \%$ ( $n=5$ patients) had DSR. Nevertheless, no statistically significant differences between the appropriateness of initial antibiotic therapy and the pattern of CRP kinetics was found $(p=0.265)$.

The median value of appropriate duration of antibiotic therapy was 10.0 (IQR, $9.0-20.0)$ for the FR group, 8.5 (IQR, 7.5 - 12.5) for the DFR group and 11.0 (IQR, 7.5 - 14.0) for the DSR group, We did not find statistically significant differences between the kinetics group and appropriate duration of antibiotic therapy $(p=0.939)$.

\section{DISCUSSION}

CRP kinetics has recently been studied to evaluate response and prognosis in patients in the ICU. ${ }^{23}$ Our results suggest that there is no association between the CRP kinetics pattern and both early and late mortality. In the past, several studies have suggested CRP serum levels as a mortality predictor. ${ }^{24-26}$

In ventilator associated pneumonia, a decrease in CRP serum levels after four days of antibiotic therapy can predict survival. ${ }^{27,28} \mathrm{CRP}$ levels on day 3 , and mainly on day 5 or 7 , compared to admission, provide important prognostic information in CAP patients and may be useful in the assessment of individual clinical evolution. ${ }^{29,30}$ The CRP ratio on

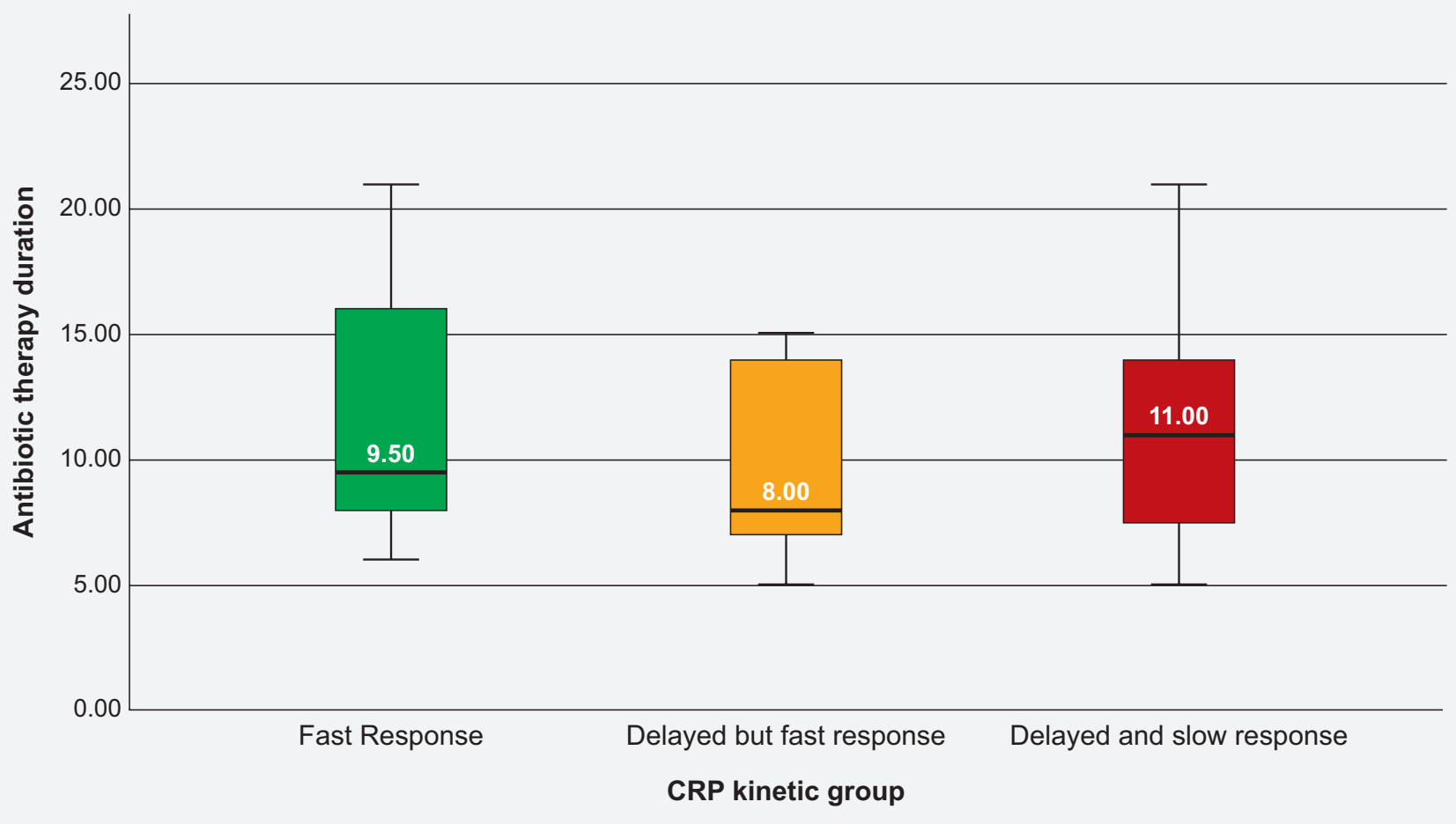

Figure 3 - Total duration of antibiotic therapy by C-reactive protein kinetic groups 
Table 3 - Antibiotic therapy appropriateness by C-reactive protein kinetic group

\begin{tabular}{lcccc}
\hline & & \multicolumn{3}{c}{ CRP kinetic group } \\
\cline { 2 - 5 } $\begin{array}{l}\text { Antibiotic } \\
\text { therapy } \\
\text { appropriateness }\end{array}$ & $\mathbf{N}$ & $\begin{array}{c}\text { FR } \\
\mathbf{n}(\%)\end{array}$ & $\begin{array}{c}\text { DFR } \\
\mathbf{n}(\%)\end{array}$ & $\begin{array}{c}\text { DSR } \\
\mathbf{n}(\%)\end{array}$ \\
\hline AAT & 39 & $11(28.2)$ & $8(20.5)$ & $20(51.3)$ \\
IAT & 8 & $0(0.0)$ & $3(37.5)$ & $5(62.5)$ \\
$p$-value & & & & $0.265^{*}$ \\
\hline
\end{tabular}

AAT: appropriate antibiotic therapy; IAT: inappropriate antibiotic therapy; CRP: C-reactive protein; FR: fast response; DFR: delayed but fast response; DSR: delayed and slow response. Variables were compared by the Fisher's exact test. ${ }^{*} p$-value no statistically significant, $p$-value $>0.05$.

day 4 of therapy is also an outcome marker of the individual clinical course of patients with bacteremia. ${ }^{31}$ Furthermore, in patients with bacteremia and a SOFA score $\leq 3$ on day 1 , a CRP decline $\geq 10 \%$ between days 1 and 2 was found to be a good predictor of early clinical stability and low mortality at 30 days. Thus, the decision of a more incisive diagnostic workup and therapy may be due to the CRP non-decrease, while waiting for blood cultures results. ${ }^{32}$

In addition, a meta-analysis and systematic review concluded that the weighted mean difference of CRP levels beyond 48 hours was significantly higher in non-survivors when compared to survivors, which suggests that CRP level after 48 hours may be a good outcome predictor in critically ill patients. ${ }^{33}$

Our sample with a median SAPS II of 39 predicts an intra-hospital mortality rate of $43.8 \%$. We infer that $65 \%$ of our patients had septic shock since they received vasopressor support. However, none of the patients died in the first 8 days and a SMR of 0.45 was documented.

Previously, four different CRP ratio patterns that correlated with the outcome were described. No deaths occurred in the group of patients with a CRP ratio pattern of fast and slow response while patients with the nonresponse or biphasic response patterns had a worst SOFA score evolution. ${ }^{17}$

In our cohort, we only found three different CRP kinetics groups. Unlike previous reports, we did not find a statistically significant association between CRP kinetics and early mortality. Some explanations can be raised to justify our results: the small number of patients included, different infection acquisition sites and infection types studied and other clinical conditions or events that may influence CRP kinetics, such as trauma, surgery or infection source control management, which were not taken into account.

We further evaluated the role of CRP kinetics in the assessment of late mortality but no significant association was observed.

CRP is routinely used by ICU physicians as an auxiliary criterion for decisions regarding antibiotic therapy. Recently, Oliveira et al demonstrated that serial measurement of CRP can be useful in order to reduce antibiotic use in septic patients without apparent harm. ${ }^{34}$ Although a single CRP evaluation does not influence the decision regarding the duration of antibiotic therapy in neonatal sepsis, its serial measurement can shorten the period of antibiotic exposure and hospital stay. ${ }^{35-37}$ Despite being slightly longer in the DSR group, no significant differences in the median duration of total and appropriate antibiotic therapy existed between the three groups. This absence of differences may be due to several factors, such as: despite CRP improvement, slow clinical response may prevent ICU physicians from stopping antibiotics earlier; some pathogens (e.g., non-fermentative gram-negative bacilli) and infection types (e.g., lung abscess or necrotizing pneumonia) require longer courses of antibiotic therapy; lack of adequate source control (e.g., bacteremia secondary to intra-abdominal sepsis) or the presence of prosthetic material that cannot be removed and ICU physicians do not use CRP kinetics to decide when to stop antibiotic therapy.

CRP kinetics has also been used to evaluate the appropriateness of initial antibiotic therapy. A fast CRP decrease seems to be associated with appropriate treatment ${ }^{27}$ but the best time to assess it has not been defined. In fact, Schmit et al, found that an increase in CRP of at least $22 \mathrm{mg} / \mathrm{L}$ in the first 48 hours of antibiotic therapy was associated with ineffective initial antibiotic therapy with moderate sensitivity $(77 \%)$ and specificity $(67 \%) .{ }^{38}$ Other authors observed that, after three days of antibiotic treatment, a reduction in CRP ratio $<60 \%$ was associated with increased odds of having received inappropriate antibiotic therapy (OR 6.98; 95\% confidence interval 1.56 - 31.33). ${ }^{22}$ According to Lisboa et al, a CRP ratio of 0.8 at 96 hours shows a good discriminatory power (area under the receiver operating characteristic curve of $0.86 ; 95 \%$ confidence interval $0.75-0.96$ ) to predict appropriateness of antibiotic therapy. ${ }^{39}$

In our cohort, no clear association between CRP kinetics and appropriateness of antibiotic therapy was observed. Nevertheless, most patients with FR received initial appropriate antibiotic therapy. On the other hand, a delayed decrease in CRP was observed if initial antibiotic therapy was inappropriate. This suggests that CRP ratio on day 4 of antibiotic therapy may play a role in the assessment of initial antibiotic adequacy.

This study has several limitations that may have influenced our results. First, this was a small retrospective observational single center study which may limit the generalizability of our results. Second, clinical conditions as well as therapies that could influence CRP kinetics during the course of the infection were not analyzed. Third, the retrospective nature of the study did not allow us to compare CRP kinetics with other biomarkers or score evolution, such as SOFA score, that have also been recommended in the assessment of response to therapy. Finally, the CRP value may be higher in patients initially admitted to the ICU compared to patients admitted to the hospital ward. This could be justified by the fact that the former are in critical condition with a higher level of inflammatory response when compared to the second group even though it is important to point out that CRP can be influenced by countless factors. For example, most co-morbidities may raise the CRP level but there are some that may not raise or may even decrease the CRP level. 


\section{CONCLUSION}

Our results suggest that the use of CRP ratio kinetics during the first seven days of antibiotic therapy is not significantly associated with both early and late mortality. Although there was not a statistically significant association between CRP kinetics patterns and antibiotic therapy appropriateness, no patient with inappropriate therapy had a FR CRP pattern. According to our data, we verified that the duration of antibiotic therapy, both total and appropriate, was similar among the different CRP kinetics groups.

Further large prospective studies are needed to clarify and standardize the role of CRP kinetics in response and prognosis assessment in infected critically ill patients.

\section{ACKNOWLEDGEMENTS}

The authors are deeply grateful to Liliana Fontes for her collaboration in collecting patient's data and to Professor Ana Azevedo for her collaboration in statistical analysis.

\section{PROTECTION OF HUMANS AND ANIMALS}

The authors declare that the procedures were followed according to the regulations established by the Clinical Research and Ethics Committee and to the Helsinki Declaration of the World Medical Association.

\section{DATA CONFIDENTIALITY}

The authors declare having followed the protocols in use at their working center regarding patient's data publication.

\section{CONFLICTS OF INTEREST}

All authors report no conflict of interest.

\section{FUNDING SOURCES}

This research received no specific grant from any funding agency in the public, commercial, or not-for-profit sectors.

\section{REFERENCES}

1. Vincent J, Rello J, Marshall J, Silva E, Anzueto A, Martin C, et al. International study of the prevalence and outcomes of infection in intensive care units. JAMA. 2009;302:2323-9.

2. Fry AM, Shay DK, Holman RC, Curns AT, Anderson LJ. Trends in hospitalizations for pneumonia among persons aged 65 years or older in the United States, 1988-2002. JAMA. 2005;294:2712-9.

3. Angus DC, Marrie TJ, Obrosky DS, Clermont G, Dremsizov TT, Coley C, et al. Severe community-acquired pneumonia: use of intensive care services and evaluation of American and British Thoracic Society Diagnostic criteria. Am J Respir Crit Care Med. 2002;166:717-23.

4. Fine MJ, Smith MA, Carson CA, Mutha SS, Sankey SS, Weissfeld LA, et al. Prognosis and outcomes of patients with community-acquired pneumonia. A meta-analysis. JAMA. 1996;275:134-41.

5. Havey TC, Fowler RA, Daneman N. Duration of antibiotic therapy for bacteremia: a systematic review and meta-analysis. Crit Care. 2011;15:R267.

6. Rebuck JA, Rasmussen JR, Olsen KM. Clinical aspiration-related practice patterns in the intensive care unit: a physician survey. Crit Care Med. 2001;29:2239-44.

7. Leibovici L, Shraga I, Drucker M, Konigsberger H, Samra Z, Pitlik S. The benefit of appropriate empirical antibiotic treatment in patients with bloodstream infection. J Intern Med. 1998;244:379-86.

8. Woodhead M, Blasi F, Ewig S, Garau J, Huchon G, leven M, et al. Guidelines for the management of adult lower respiratory tract infections-full version. Clin Microbiol Infect. 2011;17:E1-59.

9. Mandell LA, Wunderink RG, Anzueto A, Bartlett JG, Campbell GD, Dean NC, et al. Infectious Diseases Society of America/American Thoracic Society Consensus Guidelines on the Management of CommunityAcquired Pneumonia in Adults. Clin Infect Dis. 2007;44:S27-72.

10. Tillett WS, Francis T. Serological reactions in pneumonia with a nonprotein somatic fraction of pneumococcus. J Exp Med. 1930;52:561-71.

11. Vincent JL, Donadello K, Schmit X. Biomarkers in the critically ill patient: C-reactive protein. Crit Care Clin. 2011;27:241-51.

12. Volanakis JE. Human C-reactive protein: expression, structure, and function. Mol Immunol. 2001;38:189-97.

13. Mold C, Nakayama S, Holzer TJ, Gewurz H, Du Clos TW. C-reactive protein is protective against Streptococcus pneumoniae infection in mice. J Exp Med. 1981;154:1703-8.

14. Povoa P. C-reactive protein: a valuable marker of sepsis. Intensive Care Med. 2002;28:235-43.

15. Póvoa P, Coelho L, Almeida E, Fernandes A, Mealha R, Moreira P, et al. C-reactive protein as a marker of infection in critically ill patients. Clin Microbiol Infect. 2005;11:101-8.

16. Kingsley $\mathrm{A}$, Jones $\mathrm{V}$. Diagnosing wound infection: the use of $\mathrm{C}$-reactive protein. Wounds. 2008;4:32-46.

17. Povoa P, Coelho L, Almeida E, Fernandes A, Mealha R, Moreira P, et al. C-reactive protein as a marker of ventilator-associated pneumonia resolution: a pilot study. Eur Respir J. 2005;25:804-12.
18. Goncalves-Pereira J, Pereira JM, Ribeiro O, Baptista JP, Froes F, Paiva JA. Impact of infection on admission and of the process of care on mortality of patients admitted to the Intensive Care Unit: the INFAUCI study. Clin Microbiol Infect. 2014;20:1308-15.

19. Le Gall JR, Lemeshow S, Saulnier F. A new Simplified Acute Physiology Score (SAPS II) based on a European/North American multicenter study. JAMA. 1993;270:2957-63.

20. American Psychiatric Association. Diagnostic and statistical manual of mental disorders, $5^{\text {th }}$ ed, (DSM-5). Washington: American Psychiatric Publishing; 2013.

21. Mandell LA, Whitney CG, Dowell SF, File TM, Jr, Niederman MS, Torres A et al. Infectious Diseases Society of America/American Thoracic Society Consensus Guidelines on the Management of Community-Acquired Pneumonia in Adults. Clin Infect Dis. 2007;44:S27-72.

22. Bruns $A H$, Oosterheert JJ, Hak E, Hoepelman Al. Usefulness of consecutive C-reactive protein measurements in follow-up of severe community-acquired pneumonia. Eur Respir J. 2008;32:726-32.

23. Li Q, Gong X. Clinical significance of the detection of procalcitonin and C-reactive protein in the intensive care unit. Exp Ther Med. 2018;15:4265-70.

24. Bazeley J, Bieber B, Li Y, Morgenstern H, de Sequera P, Combe C, et al. C-reactive protein and prediction of 1-year mortality in prevalent hemodialysis patients. Clin J Am Soc Nephrol. 2011;6:2452-61.

25. Menéndez R, Martinez R, Reyes S, Mensa J, Filella X, Marcos MA et al. Biomarkers improve mortality prediction by prognostic scales in community-acquired pneumonia. Thorax. 2009;64:587-91.

26. Lobo SM, Lobo FR, Bota DP, Lopes-Ferreira F, Soliman HM, Melot C, et al. C-reactive protein levels correlate with mortality and organ failure in critically ill patients. Chest. 2003;123:2043-9.

27. Povoa P, Martin-Loeches I, Ramirez P, Bos LD, Esperatti M, Silvestre J et al. Biomarkers kinetics in the assessment of ventilator-associated pneumonia response to antibiotics - results from the BioVAP study. J Crit Care. 2017:41:91-7.

28. Seligman R, Meisner M, Lisboa TC, Hertz FT, Filippin TB, Fachel JM, et al. Decreases in procalcitonin and C-reactive protein are strong predictors of survival in ventilator-associated pneumonia. Crit Care. 2006;10:R125

29. Zhydkov A, Christ-Crain M, Thomann R, Hoess C, Henzen C, Werner Z, et al. Utility of procalcitonin, C-reactive protein and white blood cells alone and in combination for the prediction of clinical outcomes in community-acquired pneumonia. Clin Chem Lab Med. 2015;53:559-66.

30. Coelho LM, Salluh JI, Soares M, Bozza FA, Verdeal JC, Castro-FariaNeto $\mathrm{HC}$, et al. Patterns of c-reactive protein RATIO response in severe community-acquired pneumonia: a cohort study. Crit Care. 2012;16:R53.

31. Povoa P, Coelho L, Almeida E, Fernandes A, Mealha R, Moreira P, et al. Pilot study evaluating $\mathrm{C}$-reactive protein levels in the assessment of response to treatment of severe bloodstream infection. Clin Infect Dis. 2005;40:1855-7. 
32. Gutiérrez-Gutiérrez B, Morales I, Pérez-Galera S, Fernández-Riejos $P$ Retamar $\mathrm{P}$, de Cueto $\mathrm{M}$, et al. Predictive value of the kinetics of procalcitonin and $\mathrm{C}$-reactive protein for early clinical stability in patients with bloodstream infections due to Gram-negative bacteria. Diagn Microbiol Infect Dis. 2019;93:63-8.

33. Zhang Z, Ni H. C-reactive protein as a predictor of mortality in critically ill patients: a meta-analysis and systematic review. Anaesth Intensive Care. 2011;39:854-61.

34. Oliveira CF, Botoni FA, Oliveira CR, Silva CB, Pereira HA, Serufo $\mathrm{JC}$, et al. Procalcitonin versus $\mathrm{C}$-reactive protein for guiding antibiotic therapy in sepsis: a randomized trial. Crit Care Med. 2013;41:2336-43.

35. Al-Zwaini EJ. C-reactive protein: a useful marker for guiding duration of antibiotic therapy in suspected neonatal septicaemia? East Mediterr Health J. 2009;15:269-75.
36. Bomela HN, Ballot DE, Cory BJ, Cooper PA. Use of C-reactive protein to guide duration of empiric antibiotic therapy in suspected early neonatal sepsis. Pediatr Infect Dis J. 2000;19:531-5.

37. Philip AG, Mills PC. Use of C-reactive protein in minimizing antibiotic exposure: experience with infants initially admitted to a well-baby nursery. Pediatrics. 2000;106:e4.

38. Schmit X, Vincent JL. The time course of blood C-reactive protein concentrations in relation to the response to initial antimicrobial therapy in patients with sepsis. Infection. 2008;36:213-9.

39. Lisboa T, Seligman R, Diaz E, Rodriguez A, Teixeira PJ, Rello J. C-reactive protein correlates with bacterial load and appropriate antibiotic therapy in suspected ventilator-associated pneumonia. Crit Care Med. 2008;36:166-71. 